\title{
Phytoprogestins: Unexplored Food Compounds with Potential Preventive and Therapeutic Effects in Female Diseases
}

\author{
Stefania Greco ${ }^{1}$, Pamela Pellegrino ${ }^{1}$, Alessandro Zannotti ${ }^{1,2}$, , Giovanni Delli Carpini ${ }^{2}$, Andrea Ciavattini ${ }^{2}$, \\ Fernando M. Reis $^{3}(\mathbb{D})$ and Pasquapina Ciarmela ${ }^{1, *(D)}$ \\ 1 Department of Experimental and Clinical Medicine, Università Politecnica delle Marche, 60126 Ancona, Italy; \\ s.greco@staff.univpm.it (S.G.); p.pellegrino@pm.univpm.it (P.P.); a.zannotti@pm.univpm.it (A.Z.) \\ 2 Department of Specialist and Odontostomatological Clinical Sciences, Università Politecnica delle Marche, \\ 60126 Ancona, Italy; g.dellicarpini@staff.univpm.it (G.D.C.); a.ciavattini@univpm.it (A.C.) \\ 3 Department of Obstetrics and Gynecology, Universidade Federal de Minas Gerais, \\ Belo Horizonte 30130-100, Brazil; fmreis@ufmg.br \\ * Correspondence: p.ciarmela@univpm.it; Tel.: +39-0712206270
}

check for updates

Citation: Greco, S.; Pellegrino, P.; Zannotti, A.; Delli Carpini, G.; Ciavattini, A.; Reis, F.M.; Ciarmela, P. Phytoprogestins: Unexplored Food Compounds with Potential Preventive and Therapeutic Effects in Female Diseases. Nutrients 2021, 13, 4326. https://doi.org/10.3390/ nu13124326

Academic Editor: Elad Tako

Received: 4 November 2021

Accepted: 29 November 2021

Published: 30 November 2021

Publisher's Note: MDPI stays neutral with regard to jurisdictional claims in published maps and institutional affiliations.

Copyright: (c) 2021 by the authors. Licensee MDPI, Basel, Switzerland. This article is an open access article distributed under the terms and conditions of the Creative Commons Attribution (CC BY) license (https:// creativecommons.org/licenses/by/ $4.0 /)$.

\begin{abstract}
In recent years, there has been an increasing interest in natural therapies to prevent or treat female diseases. In particular, many studies have focused on searching natural compounds with less side effects than standard hormonal therapies. While phytoestrogen-based therapies have been extensively studied, treatments with phytoprogestins reported in the literature are very rare. In this review, we focused on compounds of natural origin, which have progestin effects and that could be good candidates for preventing and treating female diseases. We identified the following phytoprogestins: kaempferol, apigenin, luteolin, and naringenin. In vitro studies showed promising results such as the antitumoral effects of kaempferol, apigenin and luteolin, and the anti-fibrotic effects of naringenin. Although limited data are available, it seems that phytoprogestins could be a promising tool for preventing and treating hormone-dependent diseases.
\end{abstract}

Keywords: female disease; progesterone; phytoprogestins; phytochemical compounds

\section{Introduction}

In recent years, there has been an increasing interest in alternative and natural methods for the prevention or treatment of female diseases. In particular, many studies have focused on searching for adequate compounds with less side effects than standard hormonal therapies. Although the etiopathogenetic mechanisms of many gynecological diseases, such as endometriosis [1] and uterine fibroids [2] are still not clear, the role of steroid hormones is undoubted. Indeed, there is an important hormonal imbalance, for example, in endometriosis [3], uterine leiomyomas [4], ovarian cancer [5], and breast cancer [6].

The father of medicine, Hippocrates, proclaimed "Let food be the medicine and medicine be the food" around 25 centuries ago. In recent studies, there is a high interest in dietary phytochemicals. Phytochemicals are chemical compounds of natural origin that can be used as therapeutic or preventive agents.

Nutraceutical compounds can exert their effects on health in different ways, including through hormonal activity. Their mechanism of action is: 1 . Competition with the hormone for binding to the corresponding receptor, thanks to a structural similarity; 2 . Influence on the activity of key enzymes of the biosynthetic pathway, such as in the case of isoflavones, which are moderate aromatase inhibitors, thus reducing estrogen synthesis; 3 . Influence on the epigenome by affecting DNA methylation activity, histone modification, and microRNA regulation [7].

Phytoestrogens and phytoprogestins are phytochemical compounds of natural origin, which have estrogenic and progestagenic effects, respectively [8,9]. While phytoestrogenbased therapies have been extensively studied in the clinical setting, treatments with 
phytoprogestin are still in the preclinical stage, and their potential remains unexplored [8]. Therefore, we decided to review the current evidence supporting the preventive and therapeutic effects of phytoprogestins in female diseases.

\section{Methods}

In this narrative review, we performed a bibliographic search of studies evaluating the effects of dietary phytoprogestins on reproductive cells and tissues and the possible association of these nutritional compounds with gynecological diseases. The search was carried out on Pubmed using combinations of the following terms: phytochemicals [MeSH], flavonoids [MeSH], kaempferol, apigenin, naringenin, luteolin, women, uterine fibroids, endometriosis, ovarian cancer, and breast cancer. The search was narrowed to studies in humans or relevant animal models of human diseases and complemented by screening the reference lists of the selected articles. We also briefly review the pharmacological mechanisms of progesterone receptor activation and progesterone-based therapies in order to provide a background to the discussion of phytoprogestins.

\section{Progesterone}

Progesterone is a sex steroid hormone essential in female reproduction, including the menstrual cycle and the establishment and maintenance of pregnancy [10]. The etymology of the name derives from the Latin "pro gestationem" [11], as it allows the endometrium to pass from the proliferative to the secretory stage, facilitating the nesting of the blastocyst and is essential for maintaining pregnancy; in fact, it promotes the uterine growth and suppresses the contractility of the muscular tissue of the uterus (myometrium). In the mammary gland, it promotes the development of the gland for the secretion of milk. In addition, progesterone plays an essential role in the physiology of non-reproductive tissues, such as the cardiovascular system, the central nervous system, and bone tissue. In the brain, progesterone is neuroprotective, and its metabolite allopregnanolone is a GABAergic agonist [12,13] (Figure 1).

Steroids are ancestral molecules [11] characterized by a common base structure of cyclopentane-perhydro-phenanthrene, a polycyclic complex of 17 carbon atoms making a four-ring system. Based on the number of carbon atoms, sex steroids can be categorized into three groups: progesterone and progestins, with 21 carbon atoms, androgens, which have 19 carbon atoms, and finally estrogens, with 18 carbon atoms.

The biosynthesis of steroid hormones is the same in all organs where they are produced, such as the ovary, testis, adrenal cortex, brain, and placenta. The gonadal progesterone is mainly transported by blood to reach the target cells, while the progesterone produced by adrenal gland is mostly locally converted into glucocorticoids and androgens [14]. Progesterone circulates in the bloodstream bound to cortisol-binding globulin (approximately 10\%) and serum albumin and has a relatively short half-life of only five minutes. The metabolites mainly produced in the liver are sulfates and glucuronides, which are excreted in the urine. Circulating progesterone is converted by the kidney into a mineralocorticoid, deoxycorticosterone (DOC). During the luteal phase, pregnancy, and administration of exogenous progesterone, most circulating DOC arises from this pathway and may bring unbearable side effects [14].

Progesterone exerts its physiological effect by binding to target cells via specific nuclear progesterone receptors (PR) or by binding to membrane receptors (progesterone receptor membrane component, PGRMC, or $\mathrm{MPR}$ ). The binding with the nuclear receptors gives rise to a genomic pathway that requires a much longer response than the non-genomic one, which is triggered when progesterone binds to membrane receptors.

PRs are expressed in the human ovary [15], uterus [16], testis [17], brain [18], pancreas [19], bone tissue [20], mammary gland [21] and urinary tract [22]. PRs, together with the receptors for estradiol, mineralocorticoids, glucocorticoids, and androgens, belong to the superfamily of nuclear receptors. The nuclear progesterone receptor consists of a central binding domain for DNA (DBD) and a carboxylic terminal binding domain for the ligand 
(LBD). In addition, the receptor has transcription activation function (TAF) domains that interact with coactivators and corepressors to regulate the downstream target genes [23] (Figure 2). The newly transcribed progesterone receptor is assembled into an inactive multiprotein chaperone complex in the cytoplasm [24]. The receptor at this level must be inactive [25] since its activation occurs only in the presence of a link with the hormone, which induces a conformational change of the receptor [26].

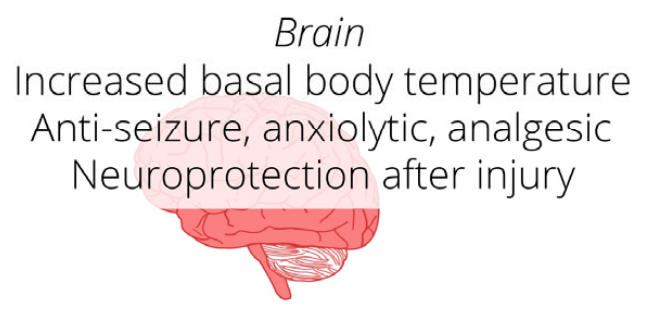

Brain

Respiratory system

Increased ventilatory response to $\mathrm{CO}_{2}$
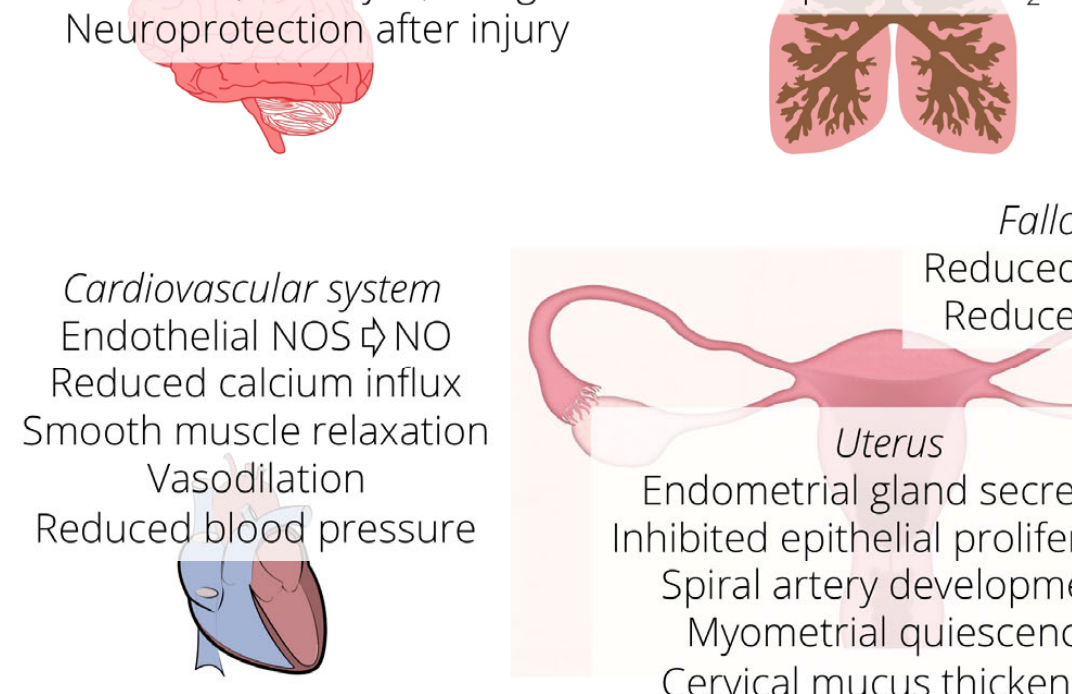

Cardiovascular system Endothelial NOS $\gg \mathrm{NO}$

Reduced calcium influx

Smooth muscle relaxation

Vasodilation

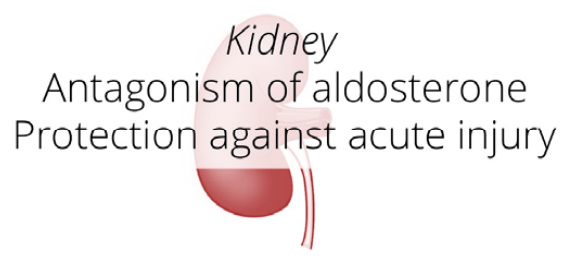

Fallopian tubes

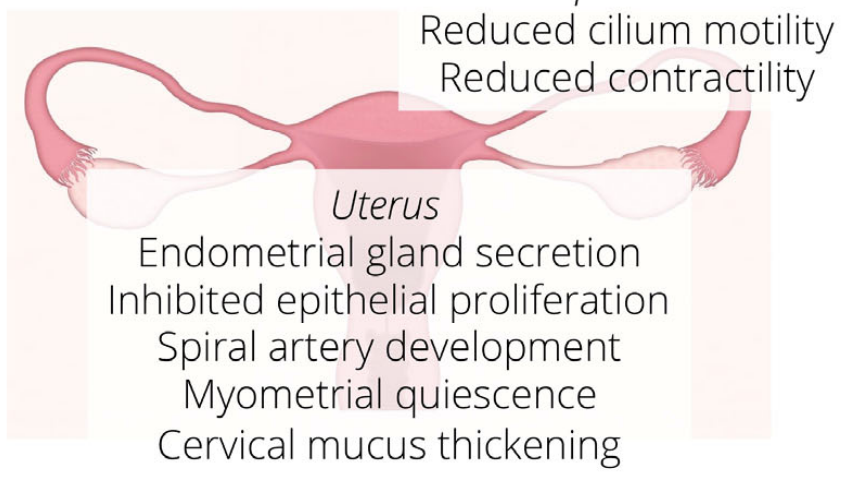

Reduced cilium motility

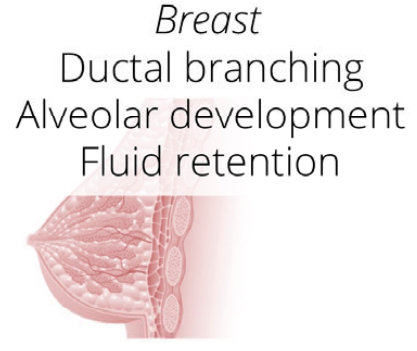

Breast

Ductal branching

Fluid retention 
(PGRMC1), its counterpart PGRMC2, and the family of membrane progesterone receptors (mPR), also known as PAQR (progestin and adipoQ) receptors [30].

Studies in mice have shown that the elimination of the PRB isoform resulted in the unhealthy development of the mammary gland [31], while the elimination of PRA caused an abnormal development of the uterus and impaired its reproductive function [32]. Therefore, in animals, a dominant expression of one of the two isoforms seems to be necessary for the normal functioning and development of some organs. On the other hand, in humans, all healthy tissues, including those of the mammary gland and uterus, have epithelial cells that express PR with the co-expression of both the PRA and PRB isoforms $[33,34]$. This condition suggests that the colocalization and thus the cooperative activity of PRA and PRB mediate the action of PR in humans. Although the two isoforms are expressed in the same way in most human tissues, there is a different expression in the endometrium. In fact, during the secretory phase of the menstrual cycle, when there are high levels of circulating progesterone, the PRA isoform is poorly expressed, resulting in a clear predominance of PRB [33].

In breast and endometrial cancers, there are substantial differences in progesterone levels and its isoforms compared to normal tissues. In fact, in healthy tissues deriving from the mammary gland, epithelial cells equally express both PR isoforms [34], while in neoplastic biopsies, it is possible to see a significant increase in the expression, alternatively, of PRA or PRB [34,35]. Similarly, in endometrial cancer, it is common to find only one of the two isoforms expressed, either PRA or PRB, suggesting that the lack of co-expression of both isoforms is an early event of the onset of endometrial cancer [36].

A third isoform (PRC) has been identified in the human placenta [37]. PRC is an isoform with a truncated $\mathrm{N}$-terminal domain, with a molecular mass of approximately $60 \mathrm{kDa}$, present in the cytoplasm. PRC lacks the first zinc finger of the DBD, but it can still bind progesterone. The actions of PRC are not clear, but it can form heterodimers with PRA and PRB and, in this way, regulate the transcriptional activity of the PR isoforms [37,38].

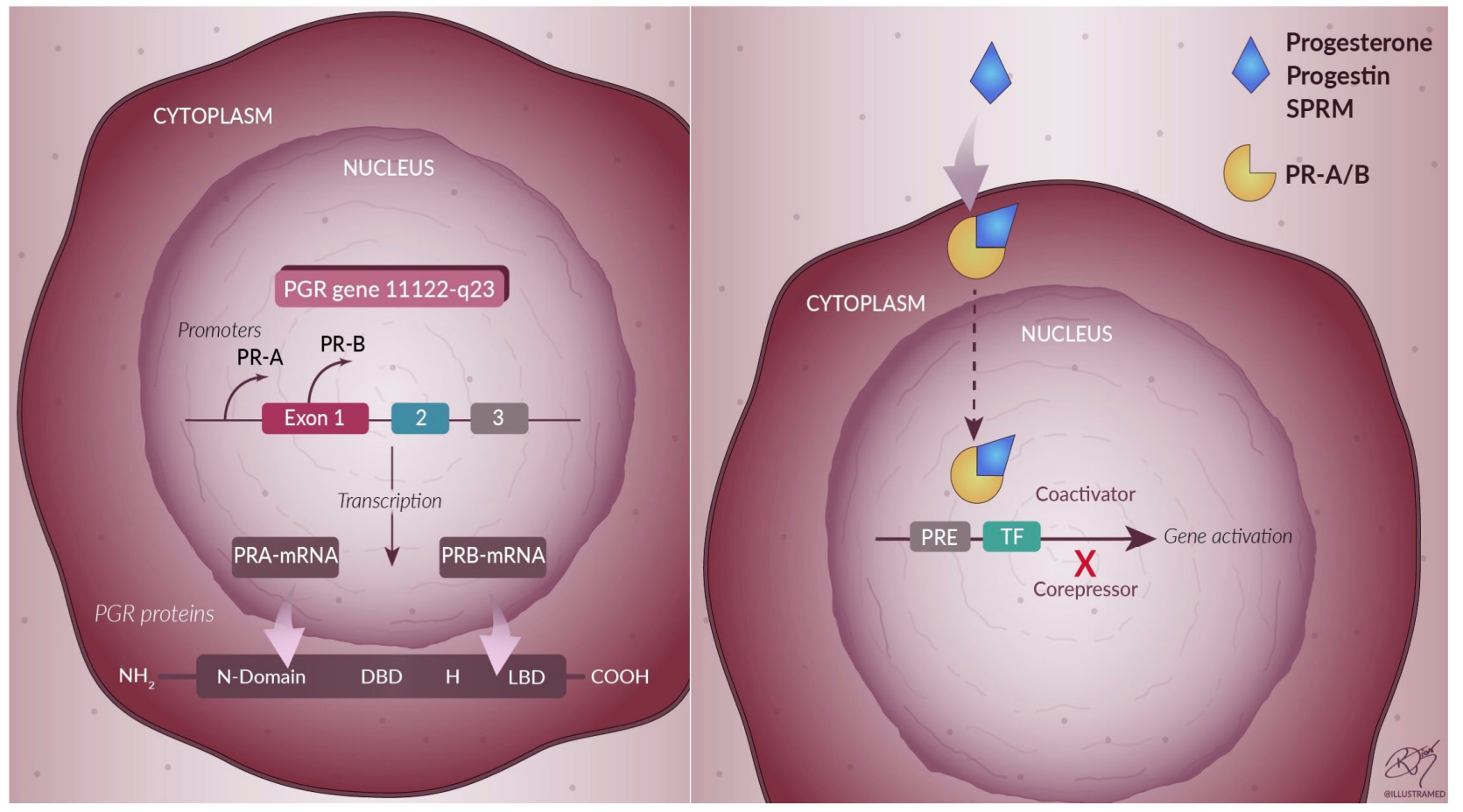

Figure 2. Progesterone receptors and their activation. The nuclear receptor is formed by two promoter regions on the PR gene, one for PRA and one for PRB, and these two promoters allow the synthesis of the two separate mRNA transcripts that code for the two different isoforms PRA and PRB. DBD = DNA-binding domain, $\mathrm{H}=$ hinge, $\mathrm{LBD}=$ ligand-binding domain, $\mathrm{SPRM}=$ selective progesterone receptor modulator, $\mathrm{PRE}=$ progesterone responsive element, $\mathrm{TF}=$ transcription factor. 


\section{Progesterone-Based Drug Therapy}

Progestogens are the most common compounds used as drug therapy for the treatment of women's diseases. Many gynecological diseases are treated with synthetic progestinbased drugs. In the United States, endometrial cancer is one of the most common gynecological cancers, with 46,470 new cases and 8,120 deaths in 2011 [39]. Even if the molecular mechanisms involved in endometrial carcinogenesis are not clear, it seems that chronic exposure to estrogen and its metabolites without sufficient counterbalance of progesterone has proliferative effects $[40,41]$ and is harmful to DNA [42,43]. Based on the antiestrogenic role of progesterone, many patients affected by endometrial cancer may have an indication to progesterone-based therapy, particularly in case of contraindications to surgery or desire for fertility maintenance. Indeed, women with endometrial hyperplasia and well-differentiated endometrial adenocarcinoma show a good response to progestogen therapy [44]. However, as the severity of the disease increases, the efficacy of progestogens decreases [45].

Other estrogen-dependent female pathologies with a high social impact, such as endometriosis, are often treated with progestin therapies $[46,47]$, including synthetic progestins such as medroxyprogesterone acetate or dienogest $[48,49]$. Uterine fibroids may also be treated with progestins. Since the first reports of decades ago [50], studies have focused on the effects of different progestins on uterine fibroids, with different drug dosages and regimens. For example, medroxyprogesterone acetate [51] and dienogest [52,53] have shown a regressive effect on uterine fibroids.

Moreover, progestogens are widely used as a contraceptive method and in menopausal hormone therapy, in combination with estrogens. These therapies may also have an effect of prevention of ovarian cancer, but they increase the risk of venous thromboembolism and present side effects $[54,55]$. Therefore, the identification of alternative progestogens is clinically significant. Numerous studies in the literature indicate a great interest in developing phytoprogestogens, such as botanical extracts or food supplements, hoping to provide the beneficial effects of progestins while avoiding the side effects.

Selective progesterone receptor modulator (SPRM) is a class of synthetic ligands that act on the PR and tend to be more tissue-specific than progestins. The mechanism of action of SPRMs occurs through binding to PR, resulting in a conformational change of the receptor. The action can be agonistic, antagonistic, or mixed. The agonist action of SPRMs involves the recruitment of different coactivators to induce transcriptional activity and occurs in tissues where high levels of coactivators are present, while antagonist activity occurs where corepressors are in excess (Figure 2).

When the PR is inactive, SPRMs bind to the receptor and activate it. The binding involves nuclear import, which gives the receptor the property of dimerization. In the nucleus, the dimer interacts with the response element in the DNA, causing the up-regulation or down-regulation of the gene [56,57]. The action of SPRMs also depends on the ratio of PR-A and PR-B in the tissue and on the specific binding affinity of the SPRMs for each receptor isoform [58]. SPRMs have been developed for clinical applications, considering their tissue selectivity and low rate of side effects [59]. Their application is principally for the treatment of uterine fibroids [60], endometriosis [61], and breast cancer [62].

Despite having beneficial effects, for example, in the treatment of uterine fibroids, the prolonged use of SPRMs may lead to endometrial hyperplasia and other side effects. Indeed, it has been shown that long-term use of the SPRM asoprisnil results in long-term damage to the endometrium. Ulipristal acetate has been approved in Canada and Europe as a presurgical therapy for patients with uterine fibroids to control bleeding, and in the United States for emergency contraception. However, it has raised concerns due to liver toxicity [63], as well as telapristone acetate, which was stopped in 2009. Vilaprisan is still under study, and its possible collateral effects are not yet known [64]. 


\section{Phytoprogestins}

Phytoprogestins are chemical compounds of vegetal origin that have progesteronelike activity and can function as non-steroidal SPRMs. Unlike estrogenic counterparts, which have been extensively studied, the literature reports much fewer studies on phytoprogestins. The following phytoprogestins have been identified: kaempferol, apigenin, luteolin, and naringenin (Figure 3).<smiles>O=c1c(O)c(-c2ccc(O)cc2)oc2cc(O)cc(O)c12</smiles>

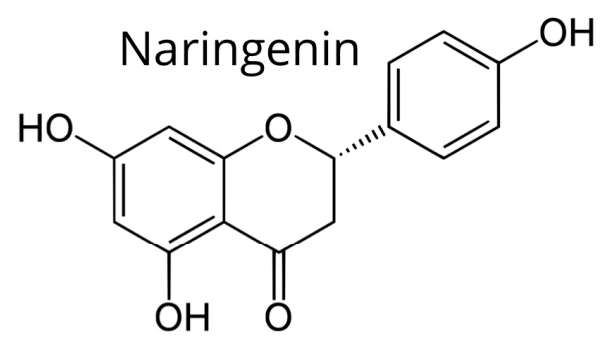<smiles>O=c1cc(-c2ccc(O)cc2)oc2cc(O)cc(O)c12</smiles>

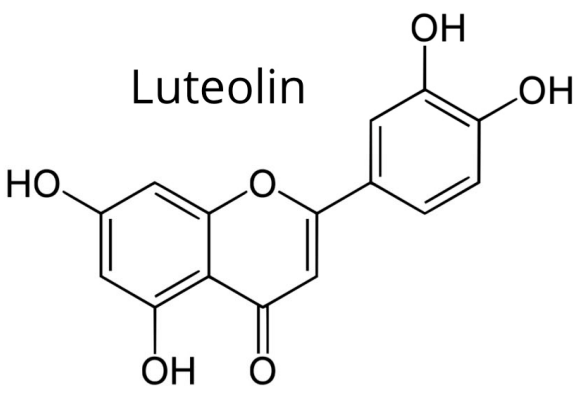

Figure 3. Chemical structure of phytoprogestins.

\subsection{Kaempferol}

Kaempferol (KP: 3,5,7-trihydroxy-2-(4-hydroxyphenyl)-4H-1-benzopyran-4-one) is a flavonoid found in several botanical families, including Pteridophyta, Pinophyta, and Magnoliophyta (Figure 3). Flavonoids are a group of secondary metabolites widespread in nature. These substances are known for the benefits of their consumption, which seems to reduce the risk of cancer and cardiovascular diseases [65]. A case-control study showed a $40 \%$ reduction (adjusted odds ratio 0.60 ) in breast cancer risk in Chinese women in the upper quartile of serum KP levels [66]. The risk of epithelial ovarian cancer was also decreased by $40 \%$ among women in the highest quintile of KP dietary intake of a large prospective cohort in the USA, the Nurses' Health Study [67]. Several studies have shown that KP has excellent antioxidant properties. In fact, it is able to decrease, even at low concentrations, the levels of the hydroxyl radical and peroxynitrite, highly reactive species capable of causing severe damage to DNA, proteins, and lipids [68]. In addition, KP has anti-inflammatory properties not only in vitro but also in vivo [69,70].

KP inhibits estrogen receptor- $\alpha$, causing antiestrogenic effects, depending on the concentration of endogenous estrogens. The antiestrogenic activity of KP results in the inhibition of the growth of hormone-dependent tumors; this activity has been demonstrated in numerous in vitro studies, for example, in endometrial carcinoma cells [71] and two lines of breast cancer cells [72].

In uterine fibroids, despite being hormone-dependent tumors with severe symptoms, the effects of KP have not been extensively studied. KP treatment reduces the expression of the estrogen receptor, thus inhibiting the cell proliferation of human uterine leiomyoma cells in vitro [73], although its therapeutic effect in vivo remains unknown (Table 1). 
Table 1. Effects of phytoprogestins that suggest their potential to treat women's diseases.

\begin{tabular}{|c|c|c|c|c|}
\hline Substance & Study Design & Effects & Significance & References \\
\hline \multirow[t]{3}{*}{ Kaempferol } & Experiments in mice and rats & Anti-inflammatory & $\begin{array}{l}\text { Could be useful to treat } \\
\text { chronic pelvic pain and } \\
\text { its causes }\end{array}$ & {$[69,70]$} \\
\hline & In vitro culture of human neutrophils & Antioxidant & $\begin{array}{l}\text { Another potential } \\
\text { therapeutic mechanism } \\
\text { to treat endometriosis }\end{array}$ & [68] \\
\hline & $\begin{array}{l}\text { In vitro culture of endometrial } \\
\text { cancer cells }\end{array}$ & $\begin{array}{l}\text { Growth inhibition } \\
\text { and apoptosis }\end{array}$ & $\begin{array}{c}\text { Could be effective } \\
\text { against endometrial } \\
\text { hyperplasia and cancer }\end{array}$ & [71] \\
\hline Apigenin & $\begin{array}{l}\text { In vitro culture of human cancer } \\
\text { cell lines }\end{array}$ & $\begin{array}{l}\text { Growth inhibition } \\
\text { and apoptosis } \\
\text { VEGF inhibition }\end{array}$ & $\begin{array}{c}\text { Could be effective } \\
\text { against endometrial } \\
\text { hyperplasia and cancer }\end{array}$ & {$[74,75]$} \\
\hline Luteolin & $\begin{array}{l}\text { Human breast tumor xenografts in } \\
\text { nude mice }\end{array}$ & $\begin{array}{l}\text { Inhibition of tumor } \\
\text { growth } \\
\text { and angiogenesis }\end{array}$ & $\begin{array}{l}\text { Could be an adjuvant } \\
\text { therapy of breast cancer }\end{array}$ & {$[76,77]$} \\
\hline \multirow[t]{2}{*}{ Naringenin } & Mouse model in vivo & $\begin{array}{c}\text { Analgesic, } \\
\text { anti-inflammatory and } \\
\text { antioxidant }\end{array}$ & $\begin{array}{l}\text { Could be useful to treat } \\
\text { chronic pelvic pain and } \\
\text { its causes }\end{array}$ & [78] \\
\hline & Rat model of hepatic injury in vivo & Antifibrotic & $\begin{array}{l}\text { Could be effective to } \\
\text { treat uterine fibroids }\end{array}$ & [79] \\
\hline
\end{tabular}

\subsection{Apigenin and Luteolin}

Apigenin (4',5,7-trihydroxyflavone) is found in a wide range of plants, including chamomile (Matricaria recutita). The traditional use of chamomile as a treatment for insomnia and anxiety has led to investigations of its active constituents, including apigenin. Apigenin is mainly present as a glycosylated compound in significant quantities in vegetables (parsley, celery, onions), fruit (oranges), herbs (chamomile, thyme, oregano, basil), and vegetable drinks (tea, beer, and wine) [80]. Apigenin is considered a phytoestrogen, although it has a much lower potency than other phytoestrogens such as genistein [81]. However, in recent studies, it has emerged that apigenin is also a phytoprogestin. A study found that apigenin reduces the risk of breast tumors in women exposed to prolonged treatment with medroxyprogesterone acetate [82,83]. A study by Horwitz and Sartorius showed that prolonged progestogen therapy could lead to the development of breast cancer through the activation of stem cells that differentiate into cancer cells [84]. In animals subjected to medroxyprogesterone therapy, apigenin administration decreased the incidence of tumors by $50 \%$ [82].

Apigenin has an antitumor effect by acting through a variety of mechanisms, including the induction of cell cycle arrest and apoptosis [74], attenuation of phosphorylation of MAP kinase [85] and inhibition of the proinflammatory cytokine interleukin-6 [86]. In vitro studies have shown that treating human breast cancer cell lines [75] with apigenin significantly reduced the expression of vascular endothelial growth factor (VEGF) and its receptor VEGFR-2 [87]. The significant reduction in VEGF disadvantages the tumor growth and development in breast tissue.

Apigenin taken orally is detectable in peripheral blood at concentrations sufficient to be biologically effective [88]. Immediately after ingestion, its concentration increases, and it remains in circulation for a long time, suggesting that it can accumulate within tissues to levels sufficient to exert chemo-preventive effects [89]. Furthermore, apigenin increased the endometrial expression of Hand2, which is a transcription factor stimulated by progesterone. The activation of Hand 2 by progesterone allows an antiproliferative action in the endometrium, further suggesting that apigenin is a phytoprogestin. Apigenin appears to be non-toxic even at high doses, as suggested by a study in which it was 
repeatedly administered to animals up to $50 \mathrm{mg} / \mathrm{kg}$ per 10-13 days, and no signs of toxicity were observed. Apigenin seems to reduce endometrial (Ishikawa) cell proliferation regardless of progesterone [90]. In vivo, apigenin is rapidly metabolized to luteolin.

Luteolin, a flavonoid found in more than 300 plant species, many of which are readily available in the human diet, has been demonstrated to be an excellent progesterone antagonist [91] (Figure 3). A study showed that luteolin effectively inhibits the growth of progestogen-dependent human xenograft tumors, inhibiting angiogenesis and limiting the conversion of breast cancer cells to stem cell-like cells [76,77]. Interestingly, preliminary results suggest that luteolin may inhibit the growth of endometriotic lesions in a mouse model [92].

\subsection{Naringenin}

Naringenin (4,5,7-dihydroxy-2-(4-hydroxyphenyl)-2,3-dihydrochromen- 4-one) belongs to the subclass of flavanones (Figure 3 ). It is a colorless compound that gives the typical bitter taste in citrus, including grapefruit, orange, and lemon [93].

Naringenin has antioxidant, immunomodulatory, anti-inflammatory, nephroprotective, hepatoprotective, neuroprotective, antidiabetic, antitumor, and anti-atherosclerotic properties. In addition, naringenin has a high bioavailability [94,95].

Naringenin is able to inhibit the recruitment and generation of reactive oxygen species (ROS), thereby reducing oxidative stress $[78,96]$. Moreover, it acts directly on the NF-KB pathway in vitro and in vivo [97]. This signaling pathway is known to be activated by external agents such as pathogens. In the presence of external agents, pro-inflammatory cytokines such as IL-1 and TNF- $\alpha$ are recalled [98]. This stimulation and this recall involve the activation of the IKB kinase complex (IKK), which eventually phosphorylates IKK $\beta$. The phosphorylated IKB allows NF-KB to translocate into the nucleus, causing inflammatory responses [99]. Naringenin can prevent the degradation of IKB, inhibiting the transcription activity of NF-KB [98].

In numerous studies, it has emerged that naringenin is also an excellent anti-fibrotic agent [79]. In fact, naringenin was able to decrease the expression of collagen, fibronectin, and Smad 3 induced by TGF- $\beta$ and to inhibit Plasminogen Activator-1 (PAI-1) in hepatic cells [100]. Some of these mechanisms are similar to those fueled by progesterone in uterine fibroids [4].

In a study by Rosenberg et al. [101] it emerged that naringenin may also have progestinlike activity. More specifically, the study showed that the progestin activity of naringenin is weak and acts at concentrations around $10^{-5}-10^{-6} \mathrm{M}$. These concentration levels are similar to those deemed necessary for the action of resveratrol as a weak estrogen [102], but not for the activity of synthetic progestins such as norgestrel and norgestimate. In fact, the biological activity of naringenin compared to norgestimate is about 104-fold lower.

The effects that naringenin as a phytoprogestin could have on diseases such as endometriosis and uterine fibroids remain to be investigated. An in vitro study found that naringenin induced apoptosis and inhibited the proliferation of immortalized cell lines derived from the endocervical epithelium of a premenopausal woman undergoing hysterectomy for endometriosis [103].

\section{Conclusions}

There is large unexplored potential in using plant-derived substances to treat human diseases. Some of these phytochemicals have been characterized as phytoprogestins, based on their similarity with progesterone and their pharmacological interaction with PR, functioning as agonists, partial agonists, or antagonists. At least four phytoprogestins have been studied in vitro with promising results such as the antitumoral effects of KP, apigenin, and luteolin, and the anti-fibrotic effects of naringenin. Although there are limited data in the literature, it appears that phytoprogestins could be a good tool for preventing and treating hormone-dependent diseases such as endometriosis, uterine fibroids, ovarian cancer, and breast cancer, with potential reduction in the side effects of currently available 
hormone treatments. The next step is to proceed with tests in well-characterized animal models to define the therapeutic mechanisms and safety of these substances, along with observational human studies correlating the dietary ingestion of phytoprogestins with the prevalence and incidence of gynecologic diseases.

Author Contributions: Writing, S.G., P.P., A.Z., G.D.C., A.C., F.M.R., P.C. All authors have read and agreed to the published version of the manuscript.

Funding: This research received no external funding.

Institutional Review Board Statement: Not applicable.

Informed Consent Statement: Not applicable.

Data Availability Statement: Not applicable.

Conflicts of Interest: The authors declare no conflict of interest.

\section{References}

1. Bulletti, C.; Coccia, M.E.; Battistoni, S.; Borini, A. Endometriosis and infertility. J. Assist. Reprod. Genet. 2010, 27, 441-447. [CrossRef]

2. Islam, M.S.; Greco, S.; Janjusevic, M.; Ciavattini, A.; Giannubilo, S.R.; D’Adderio, A.; Biagini, A.; Fiorini, R.; Castellucci, M.; Ciarmela, P. Growth factors and pathogenesis. Best Pract. Res. Clin. Obstet. Gynaecol. 2016, 34, 25-36. [CrossRef]

3. Marquardt, R.M.; Kim, T.H.; Shin, J.H.; Jeong, J.W. Progesterone and Estrogen Signaling in the Endometrium: What Goes Wrong in Endometriosis? Int. J. Mol. Sci. 2019, 20, 3822. [CrossRef] [PubMed]

4. Reis, F.M.; Bloise, E.; Ortiga-Carvalho, T.M. Hormones and pathogenesis of uterine fibroids. Best Pract. Res. Clin. Obstet. Gynaecol. 2016, 34, 13-24. [CrossRef] [PubMed]

5. Momenimovahed, Z.; Tiznobaik, A.; Taheri, S.; Salehiniya, H. Ovarian cancer in the world: Epidemiology and risk factors. Int. J. Womens Health 2019, 11, 287-299. [CrossRef]

6. Group, E.C.W. Hormones and breast cancer. Hum. Reprod. Update 2004, 10, 281-293. [CrossRef] [PubMed]

7. Dietz, B.M.; Hajirahimkhan, A.; Dunlap, T.L.; Bolton, J.L. Botanicals and Their Bioactive Phytochemicals for Women's Health. Pharmacol. Rev. 2016, 68, 1026-1073. [CrossRef]

8. Hajirahimkhan, A.; Dietz, B.M.; Bolton, J.L. Botanical modulation of menopausal symptoms: Mechanisms of action? Planta Med. 2013, 79, 538-553. [CrossRef]

9. Zava, D.T.; Dollbaum, C.M.; Blen, M. Estrogen and progestin bioactivity of foods, herbs, and spices. Proc. Soc. Exp. Biol. Med. 1998, 217, 369-378. [CrossRef]

10. Scarpin, K.M.; Graham, J.D.; Mote, P.A.; Clarke, C.L. Progesterone action in human tissues: Regulation by progesterone receptor (PR) isoform expression, nuclear positioning and coregulator expression. Nucl. Recept. Signal 2009, 7, e009. [CrossRef]

11. Taraborrelli, S. Physiology, production and action of progesterone. Acta Obstet. Gynecol. Scand. 2015, 94, 8-16. [CrossRef] [PubMed]

12. Guennoun, R. Progesterone in the Brain: Hormone, Neurosteroid and Neuroprotectant. Int. J. Mol. Sci. 2020, 21, 5271. [CrossRef] [PubMed]

13. Piette, P.C.M. The pharmacodynamics and safety of progesterone. Best Pract. Res. Clin. Obstet. Gynaecol. 2020, 69, 13-29. [CrossRef]

14. Amadori, A.; Cavallari, C.; Giacomucci, E.; Macrelli, S.; Mastronuzzi, G.; Ucci, N. Fisiologia Della Riproduzione; CLUEB: Bologna, Italy, 1994; pp. 1-92.

15. Horie, K.; Takakura, K.; Fujiwara, H.; Suginami, H.; Liao, S.; Mori, T. Immunohistochemical localization of androgen receptor in the human ovary throughout the menstrual cycle in relation to oestrogen and progesterone receptor expression. Hum. Reprod. 1992, 7, 184-190. [CrossRef] [PubMed]

16. Thijssen, J.H. Progesterone receptors in the human uterus and their possible role in parturition. J. Steroid Biochem. Mol. Biol. 2005, 97, 397-400. [CrossRef] [PubMed]

17. Abid, S.; Gokral, J.; Maitra, A.; Meherji, P.; Kadam, S.; Pires, E.; Modi, D. Altered expression of progesterone receptors in testis of infertile men. Reprod. Biomed. Online 2008, 17, 175-184. [CrossRef]

18. Brinton, R.D.; Thompson, R.F.; Foy, M.R.; Baudry, M.; Wang, J.; Finch, C.E.; Morgan, T.E.; Pike, C.J.; Mack, W.J.; Stanczyk, F.Z.; et al. Progesterone receptors: Form and function in brain. Front. Neuroendocrinol. 2008, 29, 313-339. [CrossRef]

19. Doglioni, C.; Gambacorta, M.; Zamboni, G.; Coggi, G.; Viale, G. Immunocytochemical localization of progesterone receptors in endocrine cells of the human pancreas. Am. J. Pathol. 1990, 137, 999-1005.

20. Bland, R. Steroid hormone receptor expression and action in bone. Clin. Sci. 2000, 98, 217-240. [CrossRef]

21. Branchini, G.; Schneider, L.; Cericatto, R.; Capp, E.; Brum, I.S. Progesterone receptors A and B and estrogen receptor alpha expression in normal breast tissue and fibroadenomas. Endocrine 2009, 35, 459-466. [CrossRef]

22. Batra, S.C.; Iosif, C.S. Progesterone receptors in the female lower urinary tract. J. Urol. 1987, 138, 1301-1304. [CrossRef] 
23. Lonard, D.M.; Lanz, R.B.; O'Malley, B.W. Nuclear receptor coregulators and human disease. Endocr. Rev. 2007, $28,575-587$. [CrossRef] [PubMed]

24. Smith, D.F.; Faber, L.E.; Toft, D.O. Purification of unactivated progesterone receptor and identification of novel receptor-associated proteins. J. Biol. Chem. 1990, 265, 3996-4003. [CrossRef]

25. Pratt, W.B.; Galigniana, M.D.; Morishima, Y.; Murphy, P.J. Role of molecular chaperones in steroid receptor action. Essays Biochem. 2004, 40, 41-58. [CrossRef] [PubMed]

26. Tata, J.R. Signalling through nuclear receptors. Nat. Rev. Mol. Cell Biol. 2002, 3, 702-710. [CrossRef] [PubMed]

27. Gronemeyer, H.; Meyer, M.E.; Bocquel, M.T.; Kastner, P.; Turcotte, B.; Chambon, P. Progestin receptors: Isoforms and antihormone action. J. Steroid. Biochem. Mol. Biol. 1991, 40, 271-278. [CrossRef]

28. Kastner, P.; Krust, A.; Turcotte, B.; Stropp, U.; Tora, L.; Gronemeyer, H.; Chambon, P. Two distinct estrogen-regulated promoters generate transcripts encoding the two functionally different human progesterone receptor forms A and B. EMBO J. 1990, 9, 1603-1614. [CrossRef]

29. Losel, R.M.; Besong, D.; Peluso, J.J.; Wehling, M. Progesterone receptor membrane component 1-many tasks for a versatile protein. Steroids 2008, 73, 929-934. [CrossRef]

30. Kowalik, M.K.; Rekawiecki, R.; Kotwica, J. The putative roles of nuclear and membrane-bound progesterone receptors in the female reproductive tract. Reprod. Biol. 2013, 13, 279-289. [CrossRef] [PubMed]

31. Mulac-Jericevic, B.; Lydon, J.P.; DeMayo, F.J.; Conneely, O.M. Defective mammary gland morphogenesis in mice lacking the progesterone receptor B isoform. Proc. Natl. Acad. Sci. USA 2003, 100, 9744-9749. [CrossRef]

32. Mulac-Jericevic, B.; Mullinax, R.A.; De Mayo, F.J.; Lydon, J.P.; Conneely, O.M. Subgroup of reproductive functions of progesterone mediated by progesterone receptor-B isoform. Science 2000, 289, 1751-1754. [CrossRef] [PubMed]

33. Mote, P.A.; Balleine, R.L.; McGowan, E.M.; Clarke, C.L. Colocalization of progesterone receptors A and B by dual immunofluorescent histochemistry in human endometrium during the menstrual cycle. J. Clin. Endocrinol. Metab. 1999, 84, 2963-2971. [CrossRef] [PubMed]

34. Mote, P.A.; Bartow, S.; Tran, N.; Clarke, C.L. Loss of co-ordinate expression of progesterone receptors A and B is an early event in breast carcinogenesis. Breast Cancer Res. Treat. 2002, 72, 163-172. [CrossRef]

35. Graham, J.D.; Yeates, C.; Balleine, R.L.; Harvey, S.S.; Milliken, J.S.; Bilous, A.M.; Clarke, C.L. Characterization of progesterone receptor A and B expression in human breast cancer. Cancer Res. 1995, 55, 5063-5068. [PubMed]

36. Arnett-Mansfield, R.L.; deFazio, A.; Wain, G.V.; Jaworski, R.C.; Byth, K.; Mote, P.A.; Clarke, C.L. Relative expression of progesterone receptors A and B in endometrioid cancers of the endometrium. Cancer Res. 2001, 61, 4576-4582.

37. Taylor, A.H.; McParland, P.C.; Taylor, D.J.; Bell, S.C. The cytoplasmic 60 kDa progesterone receptor isoform predominates in the human amniochorion and placenta at term. Reprod. Biol. Endocrinol. 2009, 7, 22. [CrossRef] [PubMed]

38. Wei, L.L.; Hawkins, P.; Baker, C.; Norris, B.; Sheridan, P.L.; Quinn, P.G. An amino-terminal truncated progesterone receptor isoform, PRc, enhances progestin-induced transcriptional activity. Mol. Endocrinol. 1996, 10, 1379-1387. [CrossRef]

39. Siegel, R.; Ward, E.; Brawley, O.; Jemal, A. Cancer statistics, 2011: The impact of eliminating socioeconomic and racial disparities on premature cancer deaths. CA Cancer J. Clin. 2011, 61, 212-236. [CrossRef]

40. Key, T.J.; Pike, M.C. The dose-effect relationship between 'unopposed' oestrogens and endometrial mitotic rate: Its central role in explaining and predicting endometrial cancer risk. Br. J. Cancer 1988, 57, 205-212. [CrossRef]

41. Siiteri, P.K. Steroid hormones and endometrial cancer. Cancer Res. 1978, 38, 4360-4366.

42. Doherty, J.A.; Weiss, N.S.; Fish, S.; Fan, W.; Loomis, M.M.; Sakoda, L.C.; Rossing, M.A.; Zhao, L.P.; Chen, C. Polymorphisms in nucleotide excision repair genes and endometrial cancer risk. Cancer Epidemiol. Biomarkers Prev. 2011, 20, 1873-1882. [CrossRef] [PubMed]

43. Shibutani, S.; Ravindernath, A.; Suzuki, N.; Terashima, I.; Sugarman, S.M.; Grollman, A.P.; Pearl, M.L. Identification of tamoxifenDNA adducts in the endometrium of women treated with tamoxifen. Carcinogenesis 2000, 21, 1461-1467. [CrossRef]

44. Gompel, A. Progesterone and endometrial cancer. Best Pract. Res. Clin. Obstet. Gynaecol. 2020, 69, 95-107. [CrossRef] [PubMed]

45. Ethier, J.L.; Desautels, D.N.; Amir, E.; MacKay, H. Is hormonal therapy effective in advanced endometrial cancer? A systematic review and meta-analysis. Gynecol. Oncol. 2017, 147, 158-166. [CrossRef] [PubMed]

46. Vierikko, P.; Kauppila, A.; Ronnberg, L.; Vihko, R. Steroidal regulation of endometriosis tissue: Lack of induction of 17 betahydroxysteroid dehydrogenase activity by progesterone, medroxyprogesterone acetate, or danazol. Fertil. Steril. 1985, 43, 218-224. [CrossRef]

47. Brandon, D.D.; Erickson, T.E.; Keenan, E.J.; Strawn, E.Y.; Novy, M.J.; Burry, K.A.; Warner, C.; Clinton, G.M. Estrogen receptor gene expression in human uterine leiomyomata. J. Clin. Endocrinol. Metab. 1995, 80, 1876-1881. [CrossRef]

48. Soper, J.T.; McCarty, K.S., Jr.; Creasman, W.T.; Clarke-Pearson, D.L. Induction of cytoplasmic progesterone receptor in human endometrial carcinoma transplanted into nude mice. Am. J. Obstet. Gynecol. 1984, 150, 437-439. [CrossRef]

49. Murji, A.; Biberoglu, K.; Leng, J.; Mueller, M.D.; Romer, T.; Vignali, M.; Yarmolinskaya, M. Use of dienogest in endometriosis: A narrative literature review and expert commentary. Curr. Med. Res. Opin. 2020, 36, 895-907. [CrossRef]

50. Goodman, A.L. Progesterone therapy in uterine fibromyoma. J. Clin. Endocrinol. Metab. 1946, 6, 402-408. [CrossRef]

51. Lumbiganon, P.; Rugpao, S.; Phandhu-fung, S.; Laopaiboon, M.; Vudhikamraksa, N.; Werawatakul, Y. Protective effect of depot-medroxyprogesterone acetate on surgically treated uterine leiomyomas: A multicentre case-control study. BJOG Int. J. Obstet. Gynaecol. 1996, 103, 909-914. [CrossRef] 
52. Schindler, A.E.; Campagnoli, C.; Druckmann, R.; Huber, J.; Pasqualini, J.R.; Schweppe, K.W.; Thijssen, J.H. Classification and pharmacology of progestins. Maturitas 2008, 61, 171-180. [CrossRef] [PubMed]

53. Ichigo, S.; Takagi, H.; Matsunami, K.; Suzuki, N.; Imai, A. Beneficial effects of dienogest on uterine myoma volume: A retrospective controlled study comparing with gonadotropin-releasing hormone agonist. Arch. Gynecol. Obstet. 2011, 284, 667-670. [CrossRef] [PubMed]

54. Rott, H. Thrombotic risks of oral contraceptives. Curr. Opin. Obstet. Gynecol. 2012, 24, 235-240. [CrossRef] [PubMed]

55. Practice Committee of the American Society for Reproductive Medicine. Combined hormonal contraception and the risk of venous thromboembolism: A guideline. Fertil. Steril. 2017, 107, 43-51. [CrossRef]

56. DeMarzo, A.M.; Beck, C.A.; Onate, S.A.; Edwards, D.P. Dimerization of mammalian progesterone receptors occurs in the absence of DNA and is related to the release of the 90-kDa heat shock protein. Proc. Natl. Acad. Sci. USA 1991, 88, 72-76. [CrossRef]

57. Smith, C.L.; O'Malley, B.W. Coregulator function: A key to understanding tissue specificity of selective receptor modulators. Endocr. Rev. 2004, 25, 45-71. [CrossRef]

58. Bouchard, P.; Chabbert-Buffet, N.; Fauser, B.C. Selective progesterone receptor modulators in reproductive medicine: Pharmacology, clinical efficacy and safety. Fertil. Steril. 2011, 96, 1175-1189. [CrossRef]

59. Wilkens, J.; Male, V.; Ghazal, P.; Forster, T.; Gibson, D.A.; Williams, A.R.; Brito-Mutunayagam, S.L.; Craigon, M.; Lourenco, P.; Cameron, I.T.; et al. Uterine NK cells regulate endometrial bleeding in women and are suppressed by the progesterone receptor modulator asoprisnil. J. Immunol. 2013, 191, 2226-2235. [CrossRef]

60. Donnez, J. Uterine Fibroids and Progestogen Treatment: Lack of Evidence of Its Efficacy: A Review. J. Clin. Med. 2020, 9, 3948. [CrossRef]

61. Bressler, L.H.; Bernardi, L.A.; Snyder, M.A.; Wei, J.J.; Bulun, S. Treatment of endometriosis-related chronic pelvic pain with Ulipristal Acetate and associated endometrial changes. HSOA J. Reprod. Med. Gynaecol. Obstet. 2017, 2. [CrossRef]

62. Lee, O.; Sullivan, M.E.; Xu, Y.; Rogers, C.; Muzzio, M.; Helenowski, I.; Shidfar, A.; Zeng, Z.; Singhal, H.; Jovanovic, B.; et al. Selective Progesterone Receptor Modulators in Early-Stage Breast Cancer: A Randomized, Placebo-Controlled Phase II Windowof-Opportunity Trial Using Telapristone Acetate. Clin. Cancer Res. 2020, 26, 25-34. [CrossRef]

63. Dinis-Oliveira, R.J. Pharmacokinetics, toxicological and clinical aspects of ulipristal acetate: Insights into the mechanisms implicated in the hepatic toxicity. Drug Metab. Rev. 2021, 1-9. [CrossRef]

64. Islam, M.S.; Afrin, S.; Jones, S.I.; Segars, J. Selective Progesterone Receptor Modulators-Mechanisms and Therapeutic Utility. Endocr. Rev. 2020, 41, 643-694. [CrossRef]

65. Middleton, E., Jr.; Kandaswami, C.; Theoharides, T.C. The effects of plant flavonoids on mammalian cells: Implications for inflammation, heart disease, and cancer. Pharmacol. Rev. 2000, 52, 673-751. [PubMed]

66. Feng, X.L.; Zhan, X.X.; Zuo, L.S.; Mo, X.F.; Zhang, X.; Liu, K.Y.; Li, L.; Zhang, C.X. Associations between serum concentration of flavonoids and breast cancer risk among Chinese women. Eur. J. Nutr. 2021, 60, 1347-1362. [CrossRef] [PubMed]

67. Gates, M.A.; Tworoger, S.S.; Hecht, J.L.; De Vivo, I.; Rosner, B.; Hankinson, S.E. A prospective study of dietary flavonoid intake and incidence of epithelial ovarian cancer. Int. J. Cancer 2007, 121, 2225-2232. [CrossRef] [PubMed]

68. Wang, L.; Tu, Y.C.; Lian, T.W.; Hung, J.T.; Yen, J.H.; Wu, M.J. Distinctive antioxidant and antiinflammatory effects of flavonols. J. Agric. Food Chem. 2006, 54, 9798-9804. [CrossRef] [PubMed]

69. Orhan, I.; Kupeli, E.; Terzioglu, S.; Yesilada, E. Bioassay-guided isolation of kaempferol-3-O-beta-D-galactoside with antiinflammatory and antinociceptive activity from the aerial part of Calluna vulgaris L. J. Ethnopharmacol. 2007, 114, 32-37. [CrossRef]

70. Park, M.J.; Lee, E.K.; Heo, H.S.; Kim, M.S.; Sung, B.; Kim, M.K.; Lee, J.; Kim, N.D.; Anton, S.; Choi, J.S.; et al. The anti-inflammatory effect of kaempferol in aged kidney tissues: The involvement of nuclear factor-kappaB via nuclear factor-inducing kinase/IkappaB kinase and mitogen-activated protein kinase pathways. J. Med. Food 2009, 12, 351-358. [CrossRef]

71. Chuwa, A.H.; Sone, K.; Oda, K.; Tanikawa, M.; Kukita, A.; Kojima, M.; Oki, S.; Fukuda, T.; Takeuchi, M.; Miyasaka, A.; et al. Kaempferol, a natural dietary flavonoid, suppresses 17beta-estradiol-induced survivin expression and causes apoptotic cell death in endometrial cancer. Oncol. Lett. 2018, 16, 6195-6201. [CrossRef]

72. Hu, G.; Liu, H.; Wang, M.; Peng, W. IQ Motif Containing GTPase-Activating Protein 3 (IQGAP3) Inhibits Kaempferol-Induced Apoptosis in Breast Cancer Cells by Extracellular Signal-Regulated Kinases 1/2 (ERK1/2) Signaling Activation. Med. Sci. Monit. 2019, 25, 7666-7674. [CrossRef]

73. Li, Y.; Ding, Z.; Wu, C. Mechanistic Study of the Inhibitory Effect of Kaempferol on Uterine Fibroids In Vitro. Med. Sci. Monit. 2016, 22, 4803-4808. [CrossRef]

74. Horinaka, M.; Yoshida, T.; Shiraishi, T.; Nakata, S.; Wakada, M.; Sakai, T. The dietary flavonoid apigenin sensitizes malignant tumor cells to tumor necrosis factor-related apoptosis-inducing ligand. Mol. Cancer Ther. 2006, 5, 945-951. [CrossRef]

75. Mafuvadze, B.; Benakanakere, I.; Hyder, S.M. Apigenin blocks induction of vascular endothelial growth factor mRNA and protein in progestin-treated human breast cancer cells. Menopause 2010, 17, 1055-1063. [CrossRef] [PubMed]

76. Cook, M.T.; Liang, Y.; Besch-Williford, C.; Goyette, S.; Mafuvadze, B.; Hyder, S.M. Luteolin inhibits progestin-dependent angiogenesis, stem cell-like characteristics, and growth of human breast cancer xenografts. Springerplus 2015, 4, 444. [CrossRef] [PubMed]

77. Cook, M.T.; Liang, Y.; Besch-Williford, C.; Hyder, S.M. Luteolin inhibits lung metastasis, cell migration, and viability of triplenegative breast cancer cells. Breast Cancer 2017, 9, 9-19. [CrossRef] [PubMed] 
78. Manchope, M.F.; Calixto-Campos, C.; Coelho-Silva, L.; Zarpelon, A.C.; Pinho-Ribeiro, F.A.; Georgetti, S.R.; Baracat, M.M.; Casagrande, R.; Verri, W.A., Jr. Naringenin Inhibits Superoxide Anion-Induced Inflammatory Pain: Role of Oxidative Stress, Cytokines, Nrf-2 and the NO-cGMP-PKG-KATP Channel Signaling Pathway. PLoS ONE 2016, 11, e0153015. [CrossRef] [PubMed]

79. Lee, M.H.; Yoon, S.; Moon, J.O. The flavonoid naringenin inhibits dimethylnitrosamine-induced liver damage in rats. Biol. Pharm. Bull. 2004, 27, 72-76. [CrossRef] [PubMed]

80. Hostetler, G.L.; Ralston, R.A.; Schwartz, S.J. Flavones: Food Sources, Bioavailability, Metabolism, and Bioactivity. Adv. Nutr. 2017, 8, 423-435. [CrossRef]

81. Mabry, T.; Markham, K.R.; Thomas, M.B. The Systematic Identification of Flavonoids; Springer: Berlin/Heidelberg, Germany, 2012.

82. Mafuvadze, B.; Benakanakere, I.; Lopez Perez, F.R.; Besch-Williford, C.; Ellersieck, M.R.; Hyder, S.M. Apigenin prevents development of medroxyprogesterone acetate-accelerated 7,12-dimethylbenz(a)anthracene-induced mammary tumors in SpragueDawley rats. Cancer Prev. Res. 2011, 4, 1316-1324. [CrossRef]

83. Mafuvadze, B.; Liang, Y.; Besch-Williford, C.; Zhang, X.; Hyder, S.M. Apigenin induces apoptosis and blocks growth of medroxyprogesterone acetate-dependent BT-474 xenograft tumors. Horm. Cancer 2012, 3, 160-171. [CrossRef] [PubMed]

84. Horwitz, K.B.; Sartorius, C.A. Progestins in hormone replacement therapies reactivate cancer stem cells in women with preexisting breast cancers: A hypothesis. J. Clin. Endocrinol. Metab. 2008, 93, 3295-3298. [CrossRef]

85. Yin, F.; Giuliano, A.E.; Law, R.E.; Van Herle, A.J. Apigenin inhibits growth and induces G2/M arrest by modulating cyclin-CDK regulators and ERK MAP kinase activation in breast carcinoma cells. Anticancer Res. 2001, 21, 413-420. [PubMed]

86. Lee, H.H.; Jung, J.; Moon, A.; Kang, H.; Cho, H. Antitumor and Anti-Invasive Effect of Apigenin on Human Breast Carcinoma through Suppression of IL-6 Expression. Int. J. Mol. Sci. 2019, 20, 3143. [CrossRef] [PubMed]

87. Hyder, S.M. Sex-steroid regulation of vascular endothelial growth factor in breast cancer. Endocr. Relat. Cancer 2006, 13, 667-687. [CrossRef]

88. Meyer, H.; Bolarinwa, A.; Wolfram, G.; Linseisen, J. Bioavailability of apigenin from apiin-rich parsley in humans. Ann. Nutr. Metab. 2006, 50, 167-172. [CrossRef]

89. Chen, D.; Landis-Piwowar, K.R.; Chen, M.S.; Dou, Q.P. Inhibition of proteasome activity by the dietary flavonoid apigenin is associated with growth inhibition in cultured breast cancer cells and xenografts. Breast Cancer Res. 2007, 9, R80. [CrossRef]

90. Dean, M.; Austin, J.; Jinhong, R.; Johnson, M.E.; Lantvit, D.D.; Burdette, J.E. The Flavonoid Apigenin Is a Progesterone Receptor Modulator with In Vivo Activity in the Uterus. Horm. Cancer 2018, 9, 265-277. [CrossRef]

91. Fidelis, Q.C.; Faraone, I.; Russo, D.; Aragao Catunda, F.E., Jr.; Vignola, L.; de Carvalho, M.G.; de Tommasi, N.; Milella, L. Chemical and Biological insights of Ouratea hexasperma (A. St.-Hil.) Baill.: A source of bioactive compounds with multifunctional properties. Nat. Prod. Res. 2019, 33, 1500-1503. [CrossRef]

92. Park, S.; Lim, W.; You, S.; Song, G. Ameliorative effects of luteolin against endometriosis progression in vitro and in vivo. J. Nutr. Biochem. 2019, 67, 161-172. [CrossRef]

93. Zaidun, N.H.; Thent, Z.C.; Latiff, A.A. Combating oxidative stress disorders with citrus flavonoid: Naringenin. Life Sci. 2018, 208, 111-122. [CrossRef]

94. Pereira-Caro, G.; Borges, G.; van der Hooft, J.; Clifford, M.N.; Del Rio, D.; Lean, M.E.; Roberts, S.A.; Kellerhals, M.B.; Crozier, A. Orange juice (poly)phenols are highly bioavailable in humans. Am. J. Clin. Nutr. 2014, 100, 1378-1384. [CrossRef]

95. Kanaze, F.I.; Bounartzi, M.I.; Georgarakis, M.; Niopas, I. Pharmacokinetics of the citrus flavanone aglycones hesperetin and naringenin after single oral administration in human subjects. Eur. J. Clin. Nutr. 2007, 61, 472-477. [CrossRef] [PubMed]

96. Martinez, R.M.; Pinho-Ribeiro, F.A.; Steffen, V.S.; Caviglione, C.V.; Vignoli, J.A.; Barbosa, D.S.; Baracat, M.M.; Georgetti, S.R.; Verri, W.A., Jr.; Casagrande, R. Naringenin Inhibits UVB Irradiation-Induced Inflammation and Oxidative Stress in the Skin of Hairless Mice. J. Nat. Prod. 2015, 78, 1647-1655. [CrossRef] [PubMed]

97. Pinho-Ribeiro, F.A.; Zarpelon, A.C.; Fattori, V.; Manchope, M.F.; Mizokami, S.S.; Casagrande, R.; Verri, W.A., Jr. Naringenin reduces inflammatory pain in mice. Neuropharmacology 2016, 105, 508-519. [CrossRef] [PubMed]

98. Lawrence, T. The nuclear factor NF-kappaB pathway in inflammation. Cold Spring Harb. Perspect. Biol. 2009, 1, a001651. [CrossRef]

99. Ghosh, S.; Karin, M. Missing pieces in the NF-kappaB puzzle. Cell 2002, 109, S81-S96. [CrossRef]

100. Liu, X.; Wang, W.; Hu, H.; Tang, N.; Zhang, C.; Liang, W.; Wang, M. Smad3 specific inhibitor, naringenin, decreases the expression of extracellular matrix induced by TGF-beta1 in cultured rat hepatic stellate cells. Pharm. Res. 2006, 23, 82-89. [CrossRef]

101. Rosenberg, R.S.; Grass, L.; Jenkins, D.J.; Kendall, C.W.; Diamandis, E.P. Modulation of androgen and progesterone receptors by phytochemicals in breast cancer cell lines. Biochem. Biophys. Res. Commun. 1998, 248, 935-939. [CrossRef]

102. Gehm, B.D.; McAndrews, J.M.; Chien, P.Y.; Jameson, J.L. Resveratrol, a polyphenolic compound found in grapes and wine, is an agonist for the estrogen receptor. Proc. Natl. Acad. Sci. USA 1997, 94, 14138-14143. [CrossRef]

103. Park, S.; Lim, W.; Bazer, F.W.; Song, G. Naringenin induces mitochondria-mediated apoptosis and endoplasmic reticulum stress by regulating MAPK and AKT signal transduction pathways in endometriosis cells. Mol. Hum. Reprod. 2017, 23, 842-854. [CrossRef] [PubMed] 